\title{
DEPENDENCE OF MECHANICAL PROPERTIES ON Cu CONTENT IN AISi9Cu3(Fe) ALLOY
}

\author{
Maja Vončina, Nataša Močnik, Aleš Nagode, Antun Stoić, Milan Bizjak
}

Subject review

$\mathrm{AlSi}$ Cu3(Fe) aluminium alloy is one of the most commonly used casting aluminium alloys because their utility is based on good mechanical properties Production often leads to deviations of maximum levels for certain alloying elements, particularly copper. Since mechanical properties of the final products of these alloys strongly depend on the concentration of copper in the alloy, various concentrations of copper were added to the basic alloy whereas the chemical composition was monitored using an optical emission spectrometer, measuring Brinell hardness and doing tensile tests. Moreover, the impacts of copper on oxidizing and corrosion resistance of the experimental alloys were analysed. The alloy with 3 wt. \% Cu showed the best results.

Keywords: Al-Si-Cu alloy; corrosion resistance; mechanical properties

Ovisnost mehaničkih svojstva o sadržaju Cu u slitini AISi9Cu3(Fe)

Pregledni članak Legura aluminija AlSi9Cu3(Fe) je jedna od najčešće korištenih aluminijevih legura jer je njezina primjena temeljena na dobrim mehaničkim svojstvima. U proizvodnji često nastaju odstupanja od maksimalno dopuštenih granica pojedinih legirajućih elemenata, posebice bakra. Budući da mehanička svojstva gotovih proizvoda iz ovih legura ovise o sadržaju bakra, različiti udjeli bakra su dodavani osnovnoj leguri, a sadržaj kemijskih elemenata je praćen pomoću optičkog spektrometra, ispitivanja tvrdoće HB i mjerenja vlačne čvrstoće. Uz ova ispitivanja, analiziran je i utjecaj bakra na oksidacijska svojstva i korozijsku postojanost. Najbolji rezultati dobiveni su za 3 wt. \% udjela $\mathrm{Cu}$.

Ključne riječi: legura Al-Si-Cu; korozijska postojanost; mehanička svojstva

\section{Introduction}

Aluminium and aluminium alloys are very important in various fields due to the wide range of good properties. These properties have led to the most suitable and economical material and to the fact that aluminium has become the second most used metal, after steel. The most important properties are: low density, even when it is alloyed and good mechanical properties. There are standardized aluminium alloys that provide an optimal combination of mechanical properties, processability and good castability, good machinability, easy bonding, good corrosion resistance, it is possible to use a wide variety of surface treatments, they have high electrical conductivity (special unalloyed aluminium), they are good heat conductors, etc. $[1 \div 5]$.

In most cases, only four alloying elements are used: magnesium, zinc, copper and silicon [6]. The first and most important role of alloying elements is to increase the strength of the alloys (pure aluminium has very low strength $R_{\mathrm{p} 0,2}<60 \mathrm{MPa}$ ). The increase in strength occurs because of the formation of a solid solution, and in some cases, the dispersion hardening. On the other hand, the presence of alloying elements has a major impact on the castability. Spreading tells us whether particular casting alloys can be used in industry or not. [6] Addition of copper increases the strength of the solid solution which can be even higher if the precipitation occurs [7]. Therefore, the Al-Cu alloys in general have higher yield strength and tensile strength in a wider temperature range, in comparison with $\mathrm{Al}-\mathrm{Mg}$ alloys. Copper also reduces the corrosion resistance of the aluminium and its alloys. In this respect, it is a harmful additive and its concentration must be limited. Copper allows achieving maximum strength of the Al-Si alloy in as-cast state. Its maximum concentration is between $7 \div 8$ wt. $\%$. In any case, it does not make sense to use more than $4 \div 5$ wt. \% $\mathrm{Cu}$, whereas its maximum solubility in aluminium is only slightly larger than 4 wt. \%. The phases, which contain copper and are of eutectic origin, show a negative influence on the alloy's ductility and other mechanical properties. After aging the copper which is dissolved in aluminium may precipitate in the form of secondary precipitates. In the case of alloying the Al-Si alloys with $\mathrm{Cu}$ and $\mathrm{Mg}$, the optimum concentration of $\mathrm{Cu}$ is $1 \div 3 \mathrm{wt}$. $\%[6]$.

AlSi9Cu3(Fe) [8] alloy is mainly used in the automotive industry. It contains a relatively large amount of copper, which gives good mechanical and processing properties. The disadvantage of large amounts of copper is poor corrosion resistance. Small presence of magnesium leads to the formation of $\mathrm{Mg}_{2} \mathrm{Si}$ compound, which further improves the mechanical properties of the alloy. AlSi9Cu3(Fe) alloy has good casting characteristics. It is mainly used for the production of complex castings with thin walls that are exposed to dynamic loads [9], and for mould castings for machine and engine parts, cylinder heads, parts of electric motors, bearing blocks, castings... [10].

Table 1 Chemical composition of AlSi9Cu3(Fe) alloy after ENAC

\begin{tabular}{|c|c|c|c|c|c|c|}
\hline $\mathrm{Fe}$ & & & & & & \\
\hline $\max$ & & $\max$ & $\max$ & $\max$ & $\max$ & \\
\hline 1,3 & $8 \div 11$ & 0,55 & 0,55 & 0,15 & 0,25 & $2 \div 4$ \\
\hline $\mathrm{Pb}$ & Mg & $\mathrm{Zn}$ & $\mathrm{Sn}$ & Others & $\mathrm{Al}$ & \\
\hline $\begin{array}{l}\max \\
0,35\end{array}$ & $\begin{array}{c}0,05 \div \\
0,55\end{array}$ & $\begin{array}{c}\max \\
1,2\end{array}$ & $\begin{array}{l}\max \\
0,15\end{array}$ & $\begin{array}{c}\text { each } 0,05 ; \\
\text { together } \\
0,25\end{array}$ & Bal. & \\
\hline
\end{tabular}

Chemical composition of investigated ENACAlSi9Cu3(Fe) alloy is presented in Tab. 1. The mechanical properties of the alloy $\mathrm{AlSi} 9 \mathrm{Cu} 3(\mathrm{Fe})$ according to EN 1706:2010 are shown in Tab. 2. The tensile strength of the alloy is usually at about $240 \mathrm{MPa}$ and yield strength is about $140 \mathrm{MPa}$. Brinell hardness is about $80 \mathrm{HB}[11,12]$. 
Table 2 Some mechanical properties of AlSi9Cu3(Fe) alloy [12] \begin{tabular}{|l|l|}
\hline Tensile strength $R_{\mathrm{m}} / \mathrm{MPa}$ & Yield strength $R_{\mathrm{p} 0,2} / \mathrm{MPa}$ \\
\hline
\end{tabular}

\begin{tabular}{|c|c|}
\hline 240 & 140 \\
\hline Elongation A / \% & Brinell hardness / HB \\
\hline 1 & 80 \\
\hline
\end{tabular}

\section{Experimental work}

Since the input material AlSi9Cu3(Fe) alloy contained about 2,2 wt. $\% \mathrm{Cu}$, this was the starting copper concentration. The addition to the input material was such that 3 and 4 wt. $\% \mathrm{Cu}$ in the alloy samples were achieved, respectively. For each concentration of copper two samples were prepared. Prepared material was heated up to $730{ }^{\circ} \mathrm{C}$, then melted, the copper was added, and after 15 minutes the testing samples were cast into moulds preheated to $500{ }^{\circ} \mathrm{C}$. After that the chemical composition of AlSi9Cu3(Fe) alloys was measured. Oxidation and corrosion resistance was also investigated and hardness measurements and tensile tests were conducted. Chemical analysis was made by spectrometer OES ARL 3460. The results are shown in Tab. 3. Examination of the oxidation resistance was made with the device TGA/DSC1 made by Mettler Toledo. The samples of $5 \mathrm{~mm}$ diameter and $2 \mathrm{~mm}$ height were, in the alumina crucible, heated at heating rate of $35 \mathrm{~K} / \mathrm{min}$ up to $100{ }^{\circ} \mathrm{C}$ in the inert gas of argon and then kept at $100{ }^{\circ} \mathrm{C}$ for 12 hours in an atmosphere of air, and then cooled with cooling rate of $35 \mathrm{~K} / \mathrm{min}$ to room temperature in the inert gas argon. From the TG curves the proportion of the oxidation was measured.

Corrosion resistance was analysed with electrochemical impedance spectroscopy. Samples with a diameter of $20 \mathrm{~mm}$ and a height of $3 \mathrm{~mm}$ were ground with abrasive paper 4000\#. The measurements of corrosion resistance were made in electrolyte of 3,5\% $\mathrm{NaCl}$ solution. The sequence of the measurement was as follows: Immediately after immersion (contact of the material with the electrolyte) impedance of $50 \mathrm{kHz}$ to 500 $\mathrm{MHz}$ is measured. Then the corrosion potential is measured for 3000 seconds. This can give a graphic view of the corrosion potential regarding the measurement time, which shows how the oxide layer on the surface of the sample increases, and after a certain time stabilizes, whereas the thickness becomes constant. After 1 hour, the impedance is measured again, followed by the polarization measurements at $-100 \mathrm{mV}$ to $0 \mathrm{~V}$ and 2 $\mathrm{mV} / \mathrm{s}$. Hardness was measured according to Brinell with steel ball of a diameter $2,5 \mathrm{~mm}$ and at load of $187,5 \mathrm{~kg}$, according to SIST EN ISO 6506-1:2006. For comparison we also measured the hardness of the starting material. Simultaneously the Vickers hardness of $5 \mathrm{~kg}$ load was also measured. Tensile tests were performed on a universal tearing machine Instron 1255 according to standard SIST EN ISO 6892-1 B15. The samples for tensile tests were prepared according the standard DIN 50125:2004-01, for casting aluminium alloys. The samples were gravity casted into the previously prepared mould, and are then turned and polished to the prescribed dimension. In this way the tensile strength, yield strength, elongation and contraction of the samples that contained different concentrations of copper were measured.

\section{Results and discussion}

The average chemical composition of material and investigated samples from $\mathrm{AlSi} 9 \mathrm{Cu} 3(\mathrm{Fe})$ alloys is given in Tab. 3.

Table 3 Average chemical composition of AlSi9Cu3(Fe) alloys

\begin{tabular}{|c|c|c|c|c|}
\hline Element / wt. \% & Input material & $\mathrm{Cu} 2.2$ & $\mathrm{Cu} 3.0$ & $\mathrm{Cu} 4.0$ \\
\hline $\mathrm{Cr}$ & 0,041 & 0,055 & 0,041 & 0,040 \\
\hline $\mathrm{Mg}$ & 0,235 & 0,247 & 0,243 & 0,244 \\
\hline $\mathrm{Mn}$ & 0,271 & 0,341 & 0,277 & 0,269 \\
\hline $\mathrm{Cu}$ & 2,198 & 2,234 & 3,212 & 4,715 \\
\hline $\mathrm{Zn}$ & 0,653 & 0,675 & 0,679 & 0,682 \\
\hline $\mathrm{Ti}$ & 0,052 & 0,045 & 0,044 & 0,043 \\
\hline $\mathrm{Fe}$ & 0,729 & 0,803 & 0,682 & 0,663 \\
\hline $\mathrm{Si}$ & 10,262 & 10,123 & 10,066 & 9,868 \\
\hline $\mathrm{Al}$ & Bal. & Bal. & Bal. & Bal. \\
\hline
\end{tabular}

Oxidation curves in Fig. 1 have shown a little change in the proportion of oxidation at the relatively high concentration difference of copper in the alloy. Oxidation curves slightly fall at the beginning as a result of handling with the samples or impurities on the surface of the sample. However, the minor rise can be observed, whereas the sample with 3 wt. \% Cu. showed the best oxidation resistance.

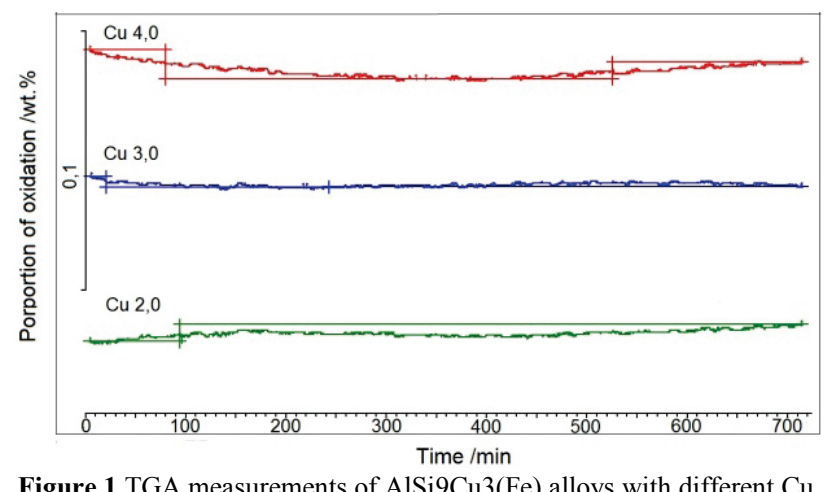

Figure 1 TGA measurements of AlSi9Cu3(Fe) alloys with different $\mathrm{Cu}$ additions

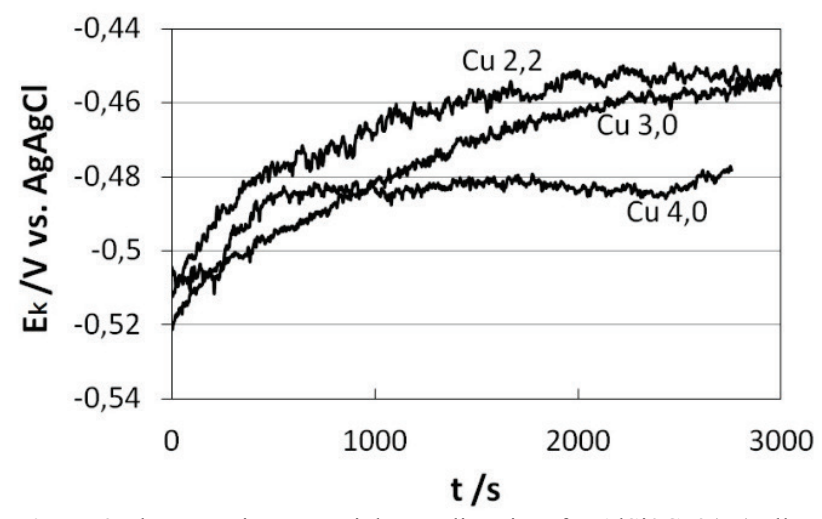

Figure 2 The corrosion potential regarding time for A1Si9Cu3(Fe) alloy with various $\mathrm{Cu}$ additions

Measurements of corrosion potential have shown that with the increasing concentration of copper in the AlSi9Cu3(Fe) alloy corrosion potential shifts to more negative values. The course of potential curves is such most likely due to the formation of certain phases in the alloy which have, in a certain concentration range 
different effect on the corrosion resistance of the AlSi9Cu3(Fe) alloy.

Table 4 Mechanical properties of AlSi9Cu3(Fe) alloy with various $\mathrm{Cu}$ additions

\begin{tabular}{|l|c|c|c|c|}
\hline & $\begin{array}{c}\text { Input } \\
\text { material }\end{array}$ & $\mathrm{Cu} 2.2$ & $\mathrm{Cu} \mathrm{3.0}$ & $\mathrm{Cu} 4.0$ \\
\hline Hardness HV & 76,9 & 105,1 & 106,1 & 105,5 \\
\hline Hardness Brinell & - & 101,7 & 106,8 & 104,7 \\
\hline$R_{\mathrm{p} 0,2} / \mathrm{MPa}$ & - & 174 & 196 & 198 \\
\hline $\mathrm{Rm} / \mathrm{MPa}$ & - & 216 & 252 & 228 \\
\hline Elongation A \% & - & 2,1 & 2,9 & 2,4 \\
\hline
\end{tabular}

The highest hardness was measured at the sample with 3 wt. $\% \mathrm{Cu}$ in the investigated alloy (Tab. 4). The hardness of the remelted sample is larger in respect of the hardness of the input material as a result of prior preparation and processing of the input material. Yield strength is the highest at the sample with larger shares of $\mathrm{Cu}$. Tensile strength is highest at the sample with 3 wt. \% $\mathrm{Cu}$, whereas elongation is also the greatest.

\section{Conclusions}

The rate of oxidation is the lowest in the sample with 3 wt. $\% \mathrm{Cu}$ but the differences are very small so the impact of $\mathrm{Cu}$ on the oxidation resistance of the alloy AlSi9Cu3(Fe) with so high concentrations of $\mathrm{Cu}$ cannot be definitely identified. The corrosion potential with the concentration of $\mathrm{Cu}$ tends to more negative values.

A similar trend can be observed at some mechanical properties regarding the addition of $\mathrm{Cu}$, namely the highest hardness values, tensile strength and elongation were observed in the alloy with 3 wt. $\% \mathrm{Cu}$, while the highest yield strength was observed at the samples with 3 and 4 wt. $\% \mathrm{Cu}$ in the investigated alloy.

AlSi9Cu3(Fe) alloy with 3 wt. \% $\mathrm{Cu}$ shows the best mechanical properties and the optimal composition of this alloy is with 3 wt. \% Cu.

\section{Acknowledgment}

Authors would like to thank Darji Kek Merl from the Institute Jožef Stefan for measurements of corrosion.

Note: The responsible translator for English language is Urška Letonja Grgeta, MOAR, Podgora, Slovenia.

\section{Literature}

[1] Kammer, C. Aluminium Handbook. Vol. 1: Fundamentals and Materials, First Edition, Aluminium-Zentrale e. V., Am Bonneshof 5, 40474 Düsseldorf. Germany, 1999.

[2] Ceschini, L.; Morri, A.; Gamberini, A.; Messieri, S. Correlation between ultimate tensile strength and solidification for the sand cast A357 Aluminium alloy. // Materials and Design. 30, 10(2009), pp. 4525-4531. DOl: 10.1016/j.matdes.2009.05.012

[3] Zeren, M.; Karakulak, E.; Gümüs, S. Influence of $\mathrm{Cu}$ addition on microstructure and hardness of near-eutectic $\mathrm{Al}-\mathrm{Si}-\mathrm{xCu}-\mathrm{alloys} . / /$ Trans. Nonferrous Met. Soc. China. 21, 8(2011), pp. 1698-1702. DOI: 10.1016/S10036326(11)60917-5

[4] Wang, G.; Bian, X.; Wang, W.; Zhang, J. Influence of $\mathrm{Cu}$ and minor elements on solution treatment of $\mathrm{Al}-\mathrm{Si}-\mathrm{Mg}-\mathrm{Cu}$ cast alloys. // Materials Letters, 57, 24-25(2003), pp. 40834087. DOI: 10.1016/s0167-577x(03)00270-2

[5] Petrič, M.; Kastelic, S.; Mrvar, P. Selection of electrodes for the "In situ" electrical resistivity measurements of molten aluminium. // J. Min. Metall. Sect. B - Metall. 49(3), B(2013), pp. 279-283.

[6] Zolotorevsky, V. S.; Belov, N. A.; Glazoff, M. V. Casting Aluminum Alloys, Elsevier, First edition, 2007.

[7] Reif, W.; Dutkiewicz, J.; Ciach, R.; Yu, S. Effect of ageing on the evolution of precipitates in AlSiCuMg alloys. // J. Krol. Materials Science and Engineering A. 30, (1997), pp. 165-168. DOI: 10.1016/S0921-5093(97)00181-0

[8] Timelli, G.; Bonollo, F. The influence of Cr content on the microstructure and mechanical properties of. AlSi9Cu3(Fe) die-casting alloys. // Materials Science and Engineering A. 528, (2010), pp. 273-282. DOI: 10.1016/j.msea.2010.08.079

[9] Kosec, G.; Nagode, A.; Budak, I.; Antić, A.; Kosec, B. Failure of the pinion from the drive of a cement mill. // Engineering Failure Analysis. 18, 1(2011), pp. 450-454. DOI: 10.1016/j.engfailanal.2010.09.033

[10] Grade 226D - AlSi9Cu3(Fe). http://www.mfggermany.com/index.php?ident $=119 \&$ lang $=2$

[11] Grade ENAC-AlSi10Mg(Fe). http://www.steelnumber.com/ en/steel_alloy_composition_eu.php?name_id=1244\#

[12] Honsel. Handbuch der gusswerkstoffe. https://www.yumpu.com/de/document/view/4530090/hand buch-der-gusswerkstoffe-honsel

\section{Authors' addresses}

Ass. Prof. Maja Vončina, Ph. D. Eng.

University of Ljubljana, Faculty of Natural Sciences and Engineering, Department of Materials and Metallurgy, Aškerčeva c. 12, 1000 Ljubljana, Slovenia

Nataša Močnik, Eng.

University of Ljubljana, Faculty of Natural Sciences and Engineering, Department of Materials and Metallurgy, Aškerčeva c. 12, 1000 Ljubljana, Slovenia

\section{Ass. Prof. Aleš Nagode, Ph. D. Eng}

University of Ljubljana, Faculty of Natural Sciences and Engineering, Department of Materials and Metallurgy, Aškerčeva c. 12, 1000 Ljubljana, Slovenia

\section{Full Prof. Antun Stoić, Ph. D. Eng.}

Mechanical Engineering Faculty in Slavonski Brod J. J. Strossmayer University of Osijek Trg Ivane Brlić Mažuranić 2 35000 Slavonski Brod, Croatia

\section{Full Prof. Milan Bizjak, Ph. D. Eng}

University of Ljubljana, Faculty of Natural Sciences and Engineering, Department of Materials and Metallurgy, Aškerčeva c. 12, 1000 Ljubljana, Slovenia 